In nearly 14000 administrations of Althesin the senior author of this paper $(R L)$ has seen only two severe adverse reactions. These were in children of 5 and 6 years old after a second maxillary antral washout for chronic sinusitis within three weeks. The reaction occurred immediately and was manifested by pronounced pallor and cardiovascular collapse with pronounced tachycardia but no bronchospasm. Both cases responded satisfactorily to intravenous administration of chlorpheniramine and hydrocortisone and ventilation with oxygen. Administering Althesin to other patients, we have observed a very low incidence of minor reactions such as flushing of the neck and shoulder region, coughing, hiccups, and limb movements. The patient discussed here, however, showed no adverse reactions, either of hypersensitivity or of untoward movement or coughing (obviously particularly important during a microlaryngoscopic procedure). The patient had the endoscopic procedures performed on a day-case basis without anatgesia. Throughout this time she has continued full schooling and is now at university. Althesin has been shown to be rapidly cleared from the plasma in animals and subsequently eliminated. ${ }^{3}$ Clinical events in this case suggest that this is so in man and makes Althesin a good choice where repeated general anaesthetics may be necessary.

We thank Mr R Pracy for his permission to report this case.

${ }^{1}$ Clarke RSJ, Dunde JW, Garrett RT, McArdle GK, Sutton JA. Adverse reactions to intravenous anaesthetics. A survey of 100 reports. $\mathrm{Br} \mathcal{F}$ Anaesth 1975; 47:575-85.

2 Evans JN, Keogh JAM. Adverse reactions to intravenous anaesthetic induction agents. $\mathrm{Br}$ Med $\mathcal{F} 1977$; $\mathrm{ii}: 735-6$.

3 Child KJ, Gibson W, Harnby G, Hart JW. Metabolism and excretion of Althesin (CT 1341) in the rat. Postgrad Med F 1972;48, suppl 2:37.

(Accepted 16 April 1982)

Royal National Throat, Nose, and Ear Hospital, London WC1X 8DA DAVID J HOWARD, FRCS, FRCSED, senior surgical registrar, professorial unit

SUSAN FARAG, DA, FFARCS, anaesthetic registrar

ROBERT M LISCOMBE, FFARCs, consultant anaesthetist

\section{Acute renal failure and rise in alkaline phosphatase activity caused by cimetidine}

Acute renal failure caused by cimetidine is rare. ${ }^{12}$ There are no reports of renal failure confirmed by a second exposure to the drug. Hepatotoxicity is also uncommon and is usually confined to a rise in serum transaminase activities. ${ }^{3}$ We describe a patient treated twice with cimetidine who developed acute renal failure and considerable rise in alkaline phosphatase activity on both occasions.

\section{Case report}

A 67-year-old man developed haematemesis and melaena in July 1980 . A barium meal examination at another hospital showed a duodenal ulcer and he was treated with cimetidine $1 \mathrm{~g}$ daily. His haemoglobin concentration was $11.7 \mathrm{~g} / \mathrm{dl}$, sodium $135 \mathrm{mmol}(\mathrm{mEq}) / \mathrm{l}$, urea $5.1 \mathrm{mmol} / 1(31 \mathrm{mg} / 100 \mathrm{ml})$ creatinine $100 \mu \mathrm{mol} / 1(1.1 \mathrm{mg} / 100 \mathrm{ml})$; and alkaline phosphatase $90 \mathrm{IU} / \mathrm{l}$ (13 KA units). Two months later he complained of excessive sweating and feeling faint. His haemoglobin was now $8.5 \mathrm{~g} / \mathrm{dl}$, sodium $123 \mathrm{mmol} / 1$, urea $19 \mathrm{mmol} / 1$ (114 mg/100 ml), creatinine $550 \mu \mathrm{mol} / 1(6.2 \mathrm{mg} / 100 \mathrm{ml})$, and alkaline phosphatase 700 IU/1 (99 KA units). Drug toxicity was suspected and his medication was discontinued. He was treated with intravenous saline and recovered uneventfully. Six weeks later his haemoglobin was $11.9 \mathrm{~g} / \mathrm{dl}$, sodium $137 \mathrm{mmol} / 1$, urea $7.6 \mathrm{mmol} / 1(46 \mathrm{mg} / 100 \mathrm{ml})$, creatinine $150 \mu \mathrm{mol} / \mathrm{l}$ $(1.7 \mathrm{mg} / 100 \mathrm{ml})$, and alkaline phosphatase $87 \mathrm{IU} / 1$ (12 KA units). Endoscopy showed duodenitis but no ulcer.

In October 1981 he complained of upper abdominal pain. A further endoscopy showed a duodenal ulcer and he was treated with cimetidine $1 \mathrm{~g}$ daily. At this time his haemoglobin was $9.7 \mathrm{~g} / \mathrm{dl}$, urea $8.6 \mathrm{mmol} / 1$ ( $52 \mathrm{mg} / 100$ $\mathrm{ml})$, creatinine $160 \mu \mathrm{mol} / 1(1.8 \mathrm{mg} / 100 \mathrm{ml})$, and alkaline phosphatase $69 \mathrm{IU} /$ (10 KA units). Three days later he was admitted urgently under our care complaining of excessive sweating and malaise. He attributed his symptoms to cimetidine. His haemoglobin was $8.7 \mathrm{~g} / \mathrm{dl}$; urea $10.2 \mathrm{mmol} / 1(61 \mathrm{mg} / 100$ $\mathrm{ml})$, creatinine $260 \mu \mathrm{mol} / \mathrm{l}(2.9 \mathrm{mg} / 100 \mathrm{ml})$, and alkaline phosphatase $74 \mathrm{IU} / \mathrm{l}$ (10 KA units). Over the next 11 days he developed high fever and progressive renal failure associated with pronounced rise of alkaline phosphatase. Blood urea rose to $40.7 \mathrm{mmol} / 1(244 \mathrm{mg} / 100 \mathrm{ml})$, creatinine to $1450 \mu \mathrm{mol} / 1(16.4 \mathrm{mg} /$ $100 \mathrm{ml}$ ), and alkaline phosphatase to $1165 \mathrm{IU} / 1$ (163 KA units). He had no rash, arthralgia, or peripheral blood eosinophilia. Cimetidine was discontinued. Three days later diuresis occurred with reversal of the biochemical abnormalities. After further gastrointestinal bleeding, vagotomy and pyloroplasty was performed on 18 January 1982 . A renal biopsy specimen taken at operation showed a focal interstitial inflammatory cell infiltrate, consisting mainly of lymphocytes and plasma cells, with associated atrophy of adjacent tubules; elsewhere the tubules appeared normal (figure). The results of

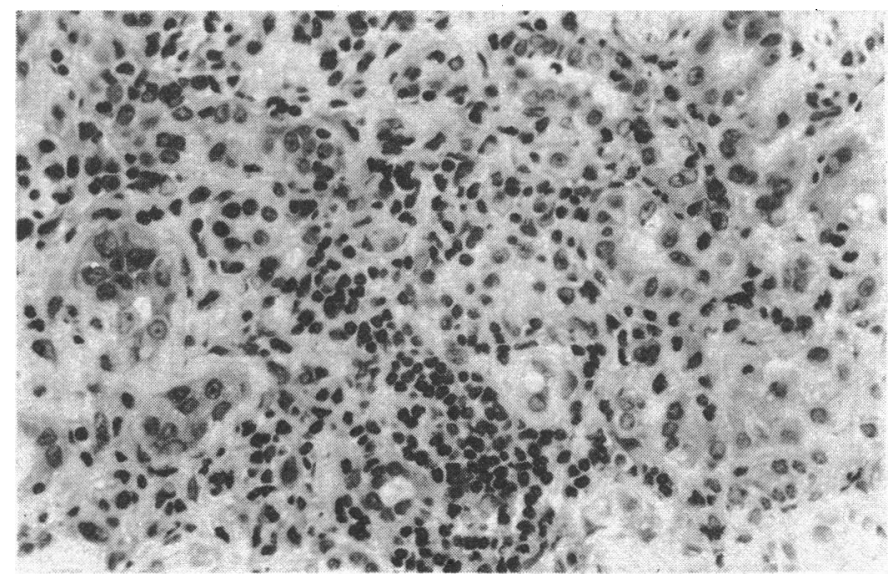

Histological findings on renal biopsy. Martius scarlet blue, plastic embedded section. $\times 600$ (original magnification).

immunofluorescence tests for IgA, IgM, Clq, C3, and fibrinogen were negative. IgG was present focally in the interstitium in relation to plasma cells. These appearances were consistent with a resolving interstitial nephritis. When discharged 10 days later his blood urea was $5.6 \mathrm{mmol} / 1$ (33.6 mg/100 $\mathrm{ml})$, creatinine $180 \mu \mathrm{mol} / \mathrm{l}(2.0 \mathrm{mg} / 100 \mathrm{ml})$, alkaline phosphatase $104 \mathrm{IU} / \mathrm{l}$ (15 KA units). The concentration of bilirubin and transaminase activities remained normal throughout.

\section{Comment}

This patient developed acute renal failure and raised serum alkaline phosphatase activity on two occasions when exposed to cimetidine. No other drug or aetiological agent could be implicated. Cimetidine increases the serum creatinine concentration in normal people but this usually remains within the normal range. The mechanism is thought to be competitive inhibition of creatinine secretion in the tubules. Acute drug-induced interstitial nephritis, however, is generally considered to be a hypersensitivity response. Immunofluorescent studies usually have negative results and dense deposits are absent on electron microscopy, suggesting that this is not an antibody-mediated reaction. ${ }^{5}$ It may be an example of delayed hypersensitivity, which might explain the rise in alkaline phosphatase in our patient.

We thank Dr A M Lessells, consultant pathologist, for reporting the histological findings of the renal biopsy specimen and providing the photomicrograph.

1 Seidelin R. Cimetidine and renal failure. Postgrad Med 7 1980;56:440-1

2 Richman AV, Narayan JL, Hirschfield JS. Acute interstitial nephritis and acute renal failure associated with cimetidine therapy. Am F Med 1981 ; $70: 1272-4$.

3 Burland WL. Evidence for the safety of cimetidine in the treatment of peptic ulcer disease. In: Proceedings of an international symposium of histamine $\mathrm{H}_{2}$-receptor antagonists. Amsterdam, Gottingen: Excerpta Medica, 1978.

4 Haggie SJ, Fermont DC, Wyllie JH. Treatment of duodenal ulcer with cimetidine. Lancet 1976; ;:983-4.

5 Linton AL, Clark WF, Driedger AA, Turnbull DI, Lindsay RM. Acute interstitial nephritis due to drugs. Ann Intern Med 1980;93:735-41.

(Accepted 16 April 1982)

University Hospital of South Manchester, Manchester M20 8LR C R PAYNE, MB, MRCP, senior medical registrar

P ACKRILL, MB, FRCP, consultant nephrologist

A J RALSTON, MB, FRCP, consultant physician 